\title{
POTENSI PENANGKAPAN RADIKAL BEBAS HASIL HIDROLISIS EKSTRAK ETANOL DAUN KEPEL (Stelechocarpus burahol, (Bl.) Hook f. \& Th.) DENGAN METODE DPPH
}

\author{
POTENTIAL OF FREE RADICALS SCAVENGING \\ OF Stelechocarpus burahol, (B1.) Hook f. \& Th. LEAVES IN \\ ETHANOL EXTRACT BY DPPH METHOD
}

Diniatik

Fakultas Farmasi, Universitas Muhammadiyah Purwokerto E-mail: diniatik@yahoo.com

\begin{abstract}
ABSTRAK
Tanaman kepel secara empiris digunakan sebagai diuretik dan pencegahan peradangan ginjal. Daunnya mengandung polifenol dan flavonoid, sedangkan daging buah, biji, dan akar mengandung saponin, flavonoid dan polifenol. Dalam penelitian ini dilakukan deteksi kandungan flavonoid dalam daun kepel dan potensi radikal bebas secara kualitatif. Simplisia daun kepel diekstraksi menggunakan metode maserasi dengan penyari etanol sebagai solven, kemudian diuapkan hingga menjadi ekstrak kental. Sebagian ekstrak etanol daun kepel dihidrolisis dengan menggunakan $\mathrm{HCl} 2 \mathrm{~N}$ selama 30 menit, kemudian difraksinasi dengan eter. Ekstrak etanol, fraksi eter, dan fraksi air asam diidentifikasi golongan senyawanya menggunakan kromatografi lapis tipis dengan fase diam silika $\mathrm{F}_{254}$ dan dua macam fase gerak BAW ( $n$-butanol: asam asetat: air $=3: 1: 1$ ) dan kloroform: metanol (8:2). Hasil kromatogram menunjukkan bahwa bercak golongan senyawa flavonoid dalam fraksi eter dan air asam dari hasil hidrolisis ekstrak etanol daun kepel mempunyai potensi sebagai penangkap radikal bebas difenilpikrilhidrazil (DPPH).
\end{abstract}

Kata kunci: Stelechocarpus burahol, DPPH, radikal bebas

\begin{abstract}
Stelechocarpus burahol, (B1.) Hook f. \& Th. is used as a medicinal plant as diuretic and prevention of kidney inflammation. The leaves contain polyphenols and flavonoids, while the fruit, seeds and roots of burahol contain saponins, flavonoids and polyphenols. In this study the detection of flavonoid content in the leaves of burahol and its potential as free radicals scavenging qualitatively. The powder of burahol leaves were extracted by maceration method using ethanol solvent, then made into a thick extract. Ethanol extracts of burahol leaves were hydrolyzed with $2 \mathrm{~N} \mathrm{HCl}$ for $30 \mathrm{~min}$, then were fractionated with ether. Ether fraction, acidic water and ethanol extracts were separated by thin-layer
\end{abstract}


chromatography with $F_{254}$ silica stationary phase and two-phase systems, there were BAW (n-butanol: acetic acid: water = 3:1:1) and chloroform: methanol (8:2). The result of this research indicating there are spots that show there are flavonoids and has potential as a scavenger diphenylpikrilhidrazil free radical (DPPH).

Keywords: Stelechocarpus burahol, DPPH, radical scavenger

\section{PENDAHULUAN}

Tanaman kepel belum digunakan secara maksimal oleh masyarakat Banyumas tapi sudah termasuk tanaman yang dimanfaatkan secara optimal di klinik Hortus Medikus, Balitbangkes Kementrian Kesehatan, Tawangmangu. Dengan kondisi geografis Banyumas yang cukup khas, yaitu curah hujan cukup tinggi dan termasuk wilayah yang dekat pegunungan Slamet dengan ketinggian 2500 dpl yang sama dengan kondisi di Tawangmangu, maka tanaman ini berpotensi untuk dikembangkan di Banyumas.

Tanaman kepel adalah salah satu tanaman yang dimanfaatkan sebagai obat, yaitu untuk diuretik dan pencegahan radang ginjal. Ekstrak etanol dan ekstrak heksan daun kepel memiliki potensi sebagai penurun kadar asam urat darah, efek hiperurikemia ekstrak etanol maupun heksana setara dengan allopurinol (Purwatiningsih dkk., 2013). Infusa daun kepel mampu menurunkan kadar asam urat dalam darah tikus (Susilowati, 2000) dan dalam ayam (Hening, 2002). Fraksi larut dan tidak larut petroleum eter daun kepel dapat menyebabkan penurunan kadar asam urat darah ayam hiperurikemia dan hasil identifikasi secara kimiawi fraksi aktif menunjukkan adanya kandungan flavonoid (Sutomo, 2003). Deteksi kandungan fraksi etanol infusa daun kepel yang dilakukan Hidayati (2004) menunjukkan adanya flavonoid. Senyawa flavonoid ini diduga mempunyai aktivitas sebagai penangkap radikal bebas, dengan demikian perlu dilakukan analisis kualitatif penangkapan radikal bebas dengan menggunakan DPPH (diphenilpikrilhidrazil), suatu radikal bebas yang sering digunakan untuk uji penangkapan radikal bebas.

Senyawa flavonoid dapat dideteksi secara kualitatif dengan menggunakan metode Kromatografi Lapis Tipis (KLT). Deteksi flavonoid dalam hal ini dapat dilakukan terhadap ekstrak etanol dan fraksi-fraksi organik dari ekstrak tersebut. 
Hasil dari deteksi tersebut dilanjutkan potensi penangkap radikal bebas DPPH secara kualitatif. Dengan demikian penelitian ini sangat penting sebagai dasar penelitian lebih lanjut tentang tanaman kepel yang merupakan tanaman asli Indonesia dan telah turun temurun digunakan sebagai penurun asam urat. Dengan dilakukan penelitian ini maka ke depan senyawa flavonoid dalam bentuk aglikon dapat diketemukan dan mekanisme sebagai penurun asam urat dapat diperoleh.

\section{METODE PENELITIAN}

Peralatan yang digunakan adalah alat-alat gelas pada umumnya, maserator, timbangan analitik, kromatografi lapis tipis. Bahan yang digunakan adalah daun kepel, etanol teknis; untuk KLT adalah berbagai fase gerak $n$-butanol-asam asetat glasial-air $(4: 1: 5, \mathrm{v} / \mathrm{v})$, asam asetat 15\%, kloroform : metanol (8:2), deteksi amoniak, DPPH (Sigma Aldrich).

Jalannya Penelitian

\section{A. Determinasi Tanaman}

Tahap ini dilakukan di Laboratorium Biologi Farmasi Fakultas Farmasi Universitas Gadjah Mada.

B. Pengumpulan dan Pengeringan Bahan

Bahan yang diambil adalah daun kepel. Bahan dicuci dengan air yang mengalir untuk menghilangkan kotoran yang menempel, kemudian dikeringkan dengan lemari pengering. Simplisia herba pegagan kemudian diserbuk menggunakan blender.

C. Pembuatan Ekstrak

Serbuk diekstraksi dengan teknik maserasi selama 2 hari, etanol 70\%, 24 jam maserasi pertama dengan satu bagian serbuk simplisia dan sepuluh bagian penyari, dilanjutkan maserasi kedua selama 24 jam dengan satu bagian serbuk dan empat bagian penyari. Maserat diuapkan penyarinya hingga diperoleh ekstrak kental etanol $70 \%$. 
D. Fraksinasi

Masing-masing ekstrak dilakukan fraksinasi dengan menggunakan heksana, kloroform, etil asetat dan sisa pelarut. Masing masing fraksi merupakan larutan sampel yang akan dilakukan uji KLT.

E. Hidrolisis

Ekstrak etanol dilakukan hidrolisis dengan menggunakan $\mathrm{HCl} \mathrm{p}$ kemudian difraksinasi dengan eter, untuk memperoleh hasil hidrolisis aglikon flavonoid. Masing-masing fraksi merupakan larutan sampel yang akan dilakukan uji KLT.

F. Analisis Kromatografi Lapis Tipis (KLT)

Uji KLT dengan:

Sistem 1:

fase gerak : $n$-butanol -asam asetat glasial-air (4:1:5,v/v), asam asetat $15 \%$.

fase diam : selulosa

deteksi : sinar UV 366 dan sinar UV 254

larutan sampel : semua fraksi

Sistem 2:

fase gerak : heksana : etil asetat $(7: 3)$

fase diam : silica $\mathrm{F}_{254}$

deteksi : sinar UV 366 dan sinar UV 254

larutan sampel : semua fraksi

G. Uji Kualitatif Penangkapan Radikal Bebas

Hasil dari KLT dilakukan penyemprotan dengan menggunakan DPPH 0,01\%. Pada bercak yang berwarna kuning dengan dasar ungu (ungu adalah warna dari pereaksi DPPH) maka senyawa tersebut berpotensi sebagai penangkap radikal bebas.

H. Pengolahan dan Analisa Data

Dilakukan analisa terhadap kromatogram yang terbentuk, warna-warna yang terbentuk setelah diuapi uap amoniak pada hasil kromatogram akan diidentifikasi dengan dicocokkan pada buku Markham (1988). Pada bercak setelah disemprot DPPH, terbentuk berwarna kuning dengan dasar ungu, maka senyawa tersebut berpotensi sebagai penangkap radikal bebas. 


\section{HASIL DAN PEMBAHASAN}

Tanaman kepel (Stelechocarpus burahol, (B1.) Hook f. \& Th.) (famili Annonaceae) yang digunakan dalam penelitian dideterminasi di Laboratorium Biologi Fakultas Farmasi, Universitas Gadjah Mada. Tujuan determinasi adalah memastikan bahwa tanaman yang diteliti adalah benar tanaman kepel, menghindari kesalahan dalam pengumpulan bahan utama penelitian. Hasil determinasi menyatakan bahwa spesimen tumbuhan tersebut adalah benar. Hasil determinasi tersebut berdasarkan buku Flora of Java Vol II (Backer and Van Den Brink, 1965). Gambar tanaman kepel terlihat pada Gambar 1.

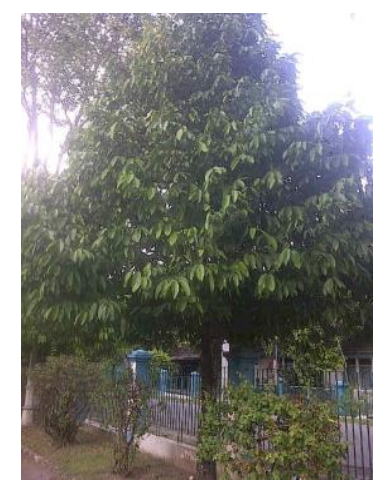

Gambar 1. Tanaman Kepel

\section{A. Pembuatan Ekstrak Etanol $70 \%$}

Daun kepel yang digunakan dalam penelitian ini diperoleh dari Yogyakarta. Metode penyarian yang digunakan adalah maserasi, yaitu merendam serbuk simplisia dengan cairan penyari. Pada penelitian ini $200 \mathrm{~g}$ serbuk simplisia dimasukkan dalam maserator kemudian direndam dengan cairan penyari (1:10) selama 24 jam agar terjadi pembasahan, dengan tujuan agar serbuk simplisia mengembang. Setelah itu disaring dan dimaserasi ulang (1:4), kemudian maserat dikumpulkan dan diuapkan hingga menjadi ekstrak kental.

Pada penelitian ini penyari yang digunakan yaitu etanol $70 \%$. Hal ini dilakukan karena berdasar penelitian Sunarni (2007) kandungan utamanya yang bersifat antioksidan adalah flavonoid. Penyari etanol $70 \%$ dapat menarik senyawa-senyawa relatif polar seperti senyawa fenol, flavonoid, saponin dan senyawa polar lain yang terkandung dalam daun dan kulit batang manggis. Dipilih 
etanol $70 \%$ karena lebih selektif, tidak beracun, netral, absorpsi baik, dapat mencegah pertumbuhan kapang dan kuman, panas yang diperlukan untuk pemekatan lebih sedikit. Sari yang diperoleh diuapkan di atas penangas air hingga konsistensi kental. Penguapan dilakukan untuk menghilangkan larutan penyari agar tidak mempengaruhi uji aktivitas antioksidan setelah didapatkan ekstrak kental dengan rata-rata rendemen $18,21 \%$, yaitu dari $100 \mathrm{~g}$ serbuk simplisia diperoleh 18,21 g ekstrak kental.

B. Analisis Kromatografi Lapis Tipis

Ekstrak yang diperoleh, difraksinasi dengan heksana, kloroform dan etil asetat, sehingga diperoleh fraksi heksana, kloroform, etil asetat dan air sisa. Masing masing fraksi dilakukan pemisahan dengan metode KLT dengan fase diam silika gel $\mathrm{F}_{254}$ dengan fase gerak heksana etil asetat 7:3 dan selulosa yang dieluasi dengan fase gerak asam asetat $15 \%$.

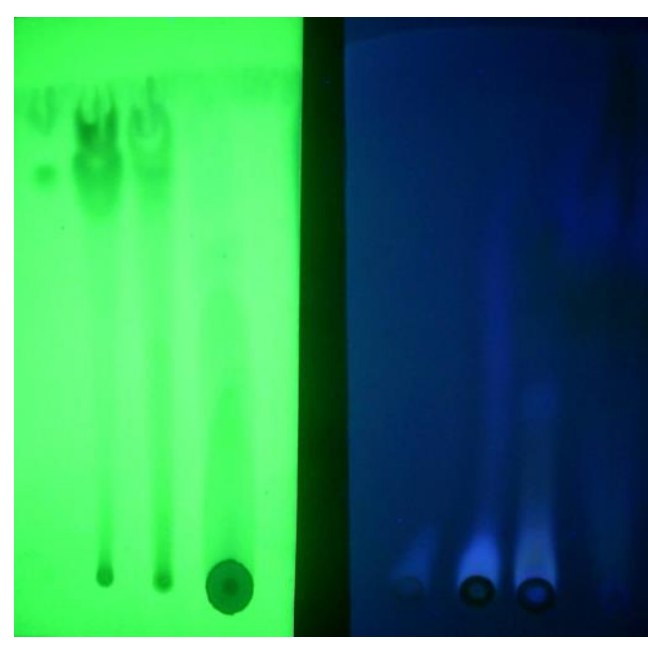

(A)
(B)

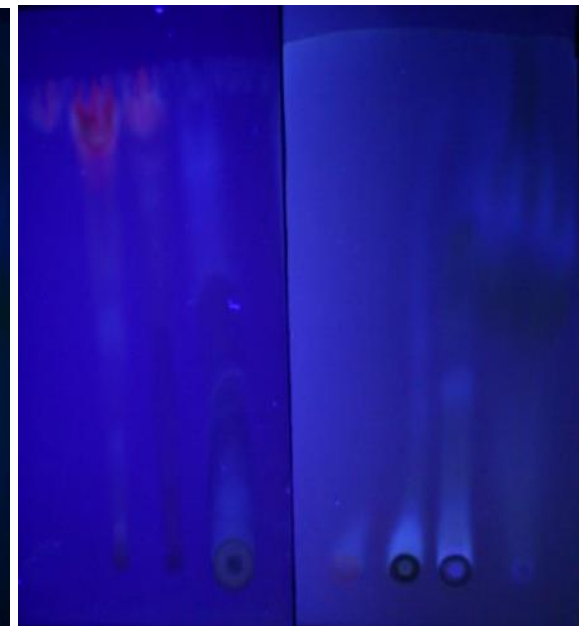

(C)

(D)

Gambar 2. Fraksi $n$-heksana, kloroform, etil asetat dan air sisa dilihat (A) fase diam silika $\mathrm{F}_{254}$ dan fase gerak kloroform : etanol (7:3) di sinar UV 254. (B) fase diam selulosa dan fase gerak asam asetat $15 \%$ di sinar UV 254. (C) fase diam silika F254 dan fase gerak kloroform : etanol (7:3) di sinar UV 366. (D) fase diam selulosa dan fase gerak asam asetat $15 \%$ di sinar UV 366.

Pada Gambar 2 dapat dilihat bahwa dengan menggunakan fase diam silika $\mathrm{F}_{254}$ dan dielusi dengan heksana: etil asetat dengan perbandingan 7:3, terdapat peredaman pada pengamatan di UV $254 \mathrm{~nm}$ yang berada pada titik penotolan, hal 
ini menunjukkan senyawa yang mempunyai gugus kromofor tidak terelusi dengan fase gerak tersebut, dengan konsentrasi terbesar adalah pada sisa air. Pada fase diam selulosa dan fase gerak asam asetat $15 \%$ dapat dilihat bahwa pada ekstrak kloroform dan etil asetat terdapat bercak yang berpendar biru pada titik penotolan, diduga senyawa ini adalah aglikon nonpolar, sedangkan pada sisa air terdapat bercak berpendar ungu dan kuning yang diduga adalah glikosida.

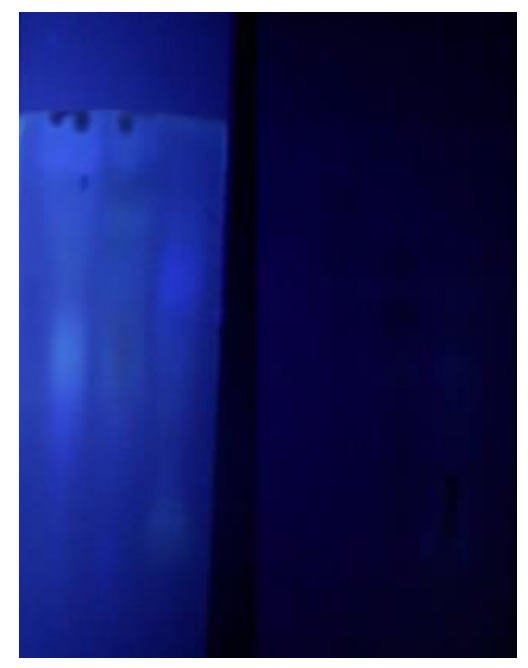

(A)

(B)

Gambar 3. Fraksi etil asetat, $n$-butanol dan sisa air dengan fase gerak BAW ( $n$-butanol: asam asetat: air $=4: 1: 5$ ) fase atas dilihat (A) fase diam selulosa di sinar UV 366. (B) fase diam silika $\mathrm{F}_{254}$ di sinar UV 366.

Pada Gambar 3 ekstrak etanol daun kepel difraksinasi dengan menggunakan etil asetat, $n$-butanol. Pada kromatogram fase diam selulosa dan fase gerak BAW ( $n$-butanol: asam asetat: air $=4: 1: 5$ ) fase atas, dilihat pada sinar UV 366. Dengan sistem kromatografi untuk mengetahui kandungan flavonoid ini, dapat dilihat bahwa pada fraksi etil asetat, $n$-butanol dan air sisa, banyak mengandung flavonoid yang masing-masing jenisnya berbeda, dengan melihat fluoresensi dominan berturut-turut kuning, ungu dan biru.

C. Analisis Kandungan Kimia Hasil Hidrolisis Ekstrak

Gambar 4 merupakan hasil kromatografi lapis tipis dari hasil hidrolisis $\mathrm{HCl}$ dari ekstrak etanol 70\% daun kepel. Ekstrak yang diperoleh, dihidrolisis dengan $\mathrm{HCl} 25 \%$ pada $\mathrm{pH}$ 2-3, kemudian difraksinasi dengan eter, sehingga diperoleh 
fraksi eter dan air sisa. Masing masing fraksi dilakukan KLT dengan fase diam silika gel $\mathrm{F}_{254}$ dan selulosa yang dielusi dengan fase gerak BAW (n-butanol: asam asetat:air $=4: 1: 5)$ fase atas. Pada Gambar 4 dapat dilihat bahwa hasil hidrolisis dari ekstrak etanol, fase nonpolar seperti glikon akan masuk dalam eter dan fase polar seperti glikon masuk dalam air asam. Hal itu tampak banyak bercak pada fase eter pada kromatogram tersebut yang terelusi cenderung di atas, dan pada air asam terdapat bercak yang cenderung di bawah. Hal tersebut karena dengan fase diam selulosa maka senyawa relatif nonpolar akan cenderung terpartisi pada fase gerak beralkohol (BAW=4:1:5).

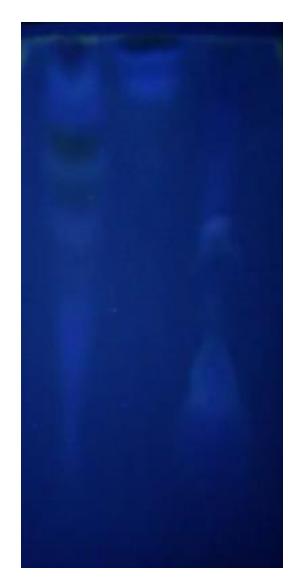

Gambar 4. Kromatogram hasil hidrolisis ekstrak etanol dalam eter dan sisa air dengan fase gerak BAW $n$-butanol: asam asetat:air $=4: 1: 5$ ) fase atas dilihat di sinar UV 366.

Ekstrak etanol daun kepel dihidrolisis agar senyawa glikosida terpisah menjadi glikon dan aglikon. Aglikon flavonoid adalah salah satu golongan senyawa yang akan dikonfirmasi keberadaannya, karena pada penelitian terdahulu dilaporkan adanya saponin, flavonoid dan polifenol (Hutapea, 1994; Sutomo, 2003; Hidayati, 2004). Diniatik dkk. (2017) melaporkan adanya aglikon flavonol yaitu kaempferol dalam fraksi etil asetat hasil hidrolisis ekstrak etanol yang mampu menghambat enzim xantin oksidase. Keberadaan aglikon flavonoid dan potensinya sebagai penangkap radikal bebas perlu dilakukan penelitian, karena flavonoid yang tidak terikat gula (aglikon flavonoid) lebih mudah berpotensi sebagai penangkap radikal bebas. Penelitian ini juga melaporkan adanya flavonoid 
dalam daun kepel. Flavonoid memiliki aktivitas antioksidan karena memiliki gugus-gugus yang berpotensi kuat sebagai penangkap radikal bebas. Menurut Pokorny dkk. (2001), gugus orto dihidroksi pada posisi 3' dan 4' cincin B pada flavonoid berpengaruh kuat sebagai antioksidan penangkap radikal bebas.

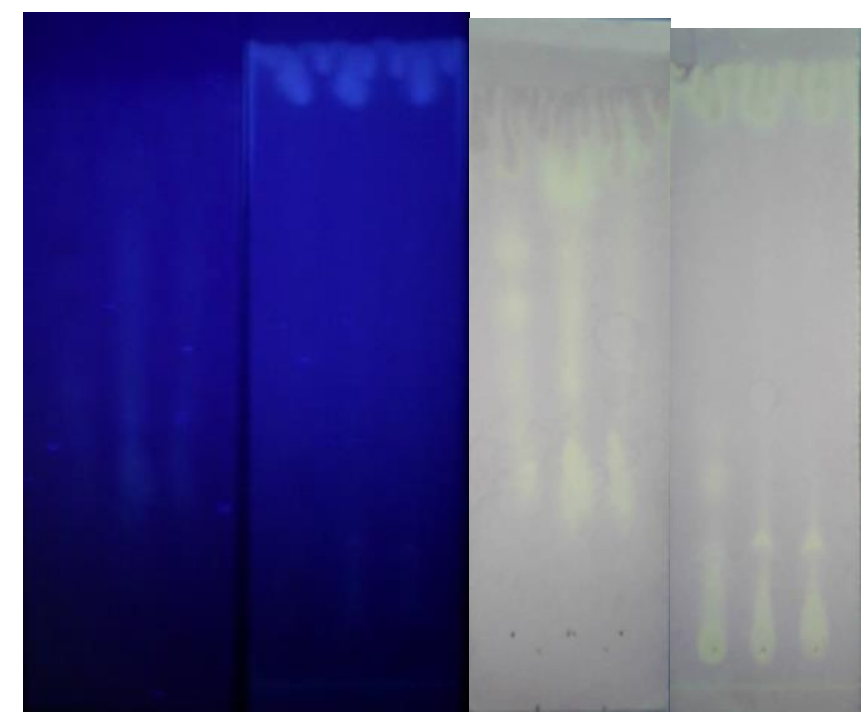
(A)
(B)
(C)
(D)

Gambar 5. Kromatogram hasil hidrolisis estrak etanol dalam eter dan sisa air dengan dilihat di sinar UV 366 (A) fase gerak BAW (n-butanol: asam asetat:air $=3: 1: 1)($ B) fase gerak kloroform : metanol (8:2) dan disemprot dengan DPPH dilihat di sinar tampak (C) fase gerak BAW (n-butanol: asam asetat:air $=3: 1: 1)$ (D) fase gerak kloroform : metanol $(8: 2)$

Pada Gambar 5 menunjukkan bahwa ekstrak etanol dan hasil hidrolisis ekstrak etanol yang diambil dengan eter mempunyai aktivitas sebagai antioksidan karena mampu menghambat radikal bebas DPPH dengan ditandai secara spontan membuat DPPH (difenilpikrilhidrazil) yang berwarna ungu menjadi difenilpikrilhidrazin yang berwarna kuning. Diniatik dkk. (2015) melaporkan bahwa di dalam fraksi etil asetat dari ektrak etanol yang telah dihidrolisis mempunyai kandungan flavonoid total yang secara signifikan lebih tinggi dibanding pada fraksi kloroform dan ekstrak etanol (Tabel I). Kadar flavonoid 
total yang tinggi pada hasil hidrolisis ekstrak etanol mempunyai aktivitas penangkapan radikal bebas yang tinggi.

Tabel I. Kadar flavonoid total fraksi etil asetat, fraksi kloroform dan ekstrak etanol daun kepel relatif terhadap pembanding rutin

\begin{tabular}{cccc}
\hline Bobot $(\mathbf{m g})$ & Absorbansi & Kadar $(\mathbf{m g} / \mathbf{m L})$ & $\begin{array}{c}\text { Kadar flavonoid } \\
\text { total } \mathbf{( \% )} / \mathbf{b})\end{array}$ \\
\hline Ekstrak & & & \\
100,1 & 0,640 & 0,204 & 10,2 \\
100,2 & 0,621 & 0,198 & 9,9 \\
100,3 & 0,581 & 0,186 & 93 \\
Rata-rata & & & 9,8 \\
\hline Fraksi etil asetat & & & \\
10,1 & 0,304 & 0,0855 & 85,50 \\
10,0 & 0,247 & 0,0656 & 65,61 \\
10,1 & 0,272 & 0,0743 & 74,33 \\
Rata-rata & & & 74,14 \\
\hline Fraksi kloroform & & & \\
30,1 & 0,270 & 0,736 & 3,07 \\
30,0 & 0,271 & 0,740 & 3,08 \\
30,3 & 0,285 & 0,789 & 3,29 \\
Rata-rata & & & 3,15 \\
\hline
\end{tabular}

\section{KESIMPULAN}

Berdasarkan hasil penelitian maka dapat disimpulkan bahwa ekstrak etanol daun kepel dan fraksi-fraksi organik dari ekstrak etanol mengandung golongan senyawa flavonoid. Senyawa yang terdapat pada ekstrak etanol, fraksi eter dari hasil hidrolisis ekstrak etanol mempunyai potensi penangkap radikal bebas DPPH.

\section{DAFTAR PUSTAKA}

Backer, C.A. dan Bakhuizen van den Brink, R.B.C., 1963, Flora of Java: Spermatophytes only, Netherlands, Vol. I, pp. 3-51, 100-102.

Diniatik, Pramono, S., Riyanto, S., 2015, Penentuan Kadar Flavonoid Total Fraksi Etil Asetat dan Fraksi Kloroform Hasil Hidrolisis Ekstrak Etanolik Daun Kepel (Stelechocarpus burahol (Bl.) Hook F. \& Th.) dengan Metode Spektrofotometri menggunakan Rutin sebagai Pembanding, Kartika Jurnal Ilmiah Farmasi, 3 (1), 54-60. 
Diniatik, Pramono, S., Riyanto, S., 2017, Kaempferol from Stelechocarpus burahol, (Bl.) Hook F. \& Th. Leaves and Xanthine Oxidase Inhibition Activity, Asian Journal of Pharmaceutical and Clinical Research, 10 (4): 322-328.

Hening, T.H.M., 2002, Efek Infusa Daun Kepel pada Kadar Asam Urat dalam Serum Hati Ayam, Skripsi, Universitas Sanata Dharma, Yogyakarta.

Hidayati, 2004, Uji Daya Melarutkan Fraksi Air dan Fraksi Etanol Infusa Daun Kepel (Stelecocharpus burahol, Hook) terhadap Batu Ginjal Kalsium secara In Vitro, Skripsi, Universitas Ahmad Dahlan, Yogyakarta.

Hutapea, J.R., 1994, Inventaris Tanaman Obat Indonesia, Pulitbang DEPKES RI.

Markham, K.R, 1988, Cara Mengidentifikasi Flavonoid, diterjemahkan oleh Kosasih Padmawinata, Bandung, ITB, 1, 10, 12, 38, 39, 48.

Pokorny, J., Yanislhieva, N., and Gordon, M., 2001, Antioxidant in Food, Marcell Dekker.

Purwatiningsih dan Nurlaila, 2013, One-day Oral Treatment Effect of the Ethanol Extract of Kepel [Stelechocarpus burahol (Bl.) Hook f. \& Th.] Leaves on the Body Weight and Organ of Sprague-Dawley Rats, IJPI Journal on Pharmacology and Toxicology, ISSN 2229-6859.

Sunarni, 2007, Flavonoid antioksidan penangkap radikal dari daun kepel (Stelechocarpus burahol (B1.) Hook f. \& Th.), Majalah Farmasi Indonesia, 18 (3): 111-116.

Susilowati, I., 2000, Uji Aktivitas Infusa Daun Kepel sebagai Penurun Kadar Asam Urat dalam Darah, Skripsi, Fakultas Farmasi, Universitas Ahmad Dahlan, Yogyakarta.

Sutomo, 2003, Penurunan Asam Urat Darah Ayam Jantan Braille hipersuremina oleh Fraksi Ekstrak Metanol Daun Kepel, Tesis, Pascasarjana, Prodi Ilmu Farmasi, Universitas Gadjah Mada, Yogyakarta. 